\title{
Sciendo
}

Rocznik Pedagogiczny 42/2019

PL ISSN 0137-9585

DOI $10.2478 / \mathrm{rp}-2019-0015$

\section{DZIAŁALNOŚĆ KNP PAN}

BOGUSŁAW ŚLIWERSKI

Akademia Pedagogiki Specjalnej

im. Marii Grzegorzewskiej w Warszawie

\section{PODSUMOWANIE DZIAŁALNOŚCI KOMITETU NAUK PEDAGOGICZNYCH PAN W LATACH 2016-2019}

Kolejna, czteroletnia kadencja przewodniczącego Komitetu Nauk Pedagogicznych PAN zobowiązuje do zdania sprawozdania z działalności korporacyjnego środowiska akademickiego, które zostało wybrane przez samodzielnych pracowników naukowych afiliowanych przy pedagogice jako dyscyplinie naukowej. Sprawozdania z poszczególnych lat zostały opublikowane na łamach „Rocznika Pedagogicznego" KNP PAN ${ }^{1}$. Dziekan Wydziału I Nauk Humanistycznych i Społecznych PAN wręczył w dn. 12 grudnia 2015 roku nominacje członkom KNP PAN. Ci zaś wybrali władze wykonawcze Komitetu, a więc jego Prezydium w osobach:

1) wiceprzewodniczących:

- prof. dr hab. Dorota KLUS-STAŃSKA - Uniwersytet Gdański

- prof. dr hab. Marek KONOPCZYŃSKI - Wyższa Szkoła Nauk Społecznych PEDAGOGIUM w Warszawie; Uniwersytet w Białymstoku

- prof. dr hab. Barbara KROMOLICKA - Uniwersytet Szczeciński

- prof. dr hab. Stefan KWIATKOWSKI - Akademia Pedagogiki Specjalnej, Warszawa

- prof. dr hab. Zbyszko MELOSIK - Uniwersytet im. Adama Mickiewicza w Poznaniu;

B. Śliwerski, Komitet Nauk Pedagogicznych PAN po pierwszym roku nowej kadencji, „Rocznik Pedagogiczny” 2016, t. 39; tenże, Informacja o działalności KNP PAN w 2017 r., „Rocznik Pedagogiczny" 2017, t. 41. 
2) członkach Prezydium:

- prof. Zenon Gajdzica (Uniwersytet Śląski);

- prof. Wiesław Jamrożek (Uniwersytet im. Adama Mickiewicza w Poznaniu);

- prof. Amadeusz Krause (Uniwersytet Gdański);

- ks. prof. Marian Nowak (Katolicki Uniwersytet Lubelski im. Jana Pawła II w Lublinie);

- prof. Mirosław Szymański (Akademia Pedagogiki Specjalnej im. Marii Grzegorzewskiej w Warszawie);

- prof. Władysława Szulakiewicz (Uniwersytet Mikołaja Kopernika w Toruniu).

3) Sekretarza Naukowego Komitetu: prof. Jerzego NIKITOROWICZA Uniwersytet w Białymstoku.

W czasie powyborczego posiedzenia nowego składu Komitetu przedstawiłem jako przewodniczący KNP zamierzenia, które powinny być podjęte w tej kadencji, wiążąc dokonania i ustalenia z przeszłości z aktywnością zorientowaną na przyszłość akademickiej pedagogiki, a w trosce o jak najwyższy stan jej rozwoju oraz kadr naukowych. Miałem tu na uwadze takie kwestie, jak:

1. Przygotowywanie ekspertyz dla instytucji rządowych i samorządowych oraz dla organów opiniodawczych, np. Centralna Komisja Do Spraw Stopnii Tytułów, Polska Akademia Nauk, Polskie Towarzystwo Pedagogiczne itp.

2. Współpraca z rektorami uniwersytetów i uczelni pedagogicznych, z dziekanami wydziałów pedagogicznych i dyrektorami instytutów pedagogicznych w uczelniach państwowych i niepublicznych.

3. Wspieranie młodych kadr naukowych w ramach:

- Letnich Szkół Młodych Pedagogów;

- Zespołu Samokształceniowego Doktorów przy KNP;

- włączania do prac w zespołach problemowych i subdyscyplinarnych KNP;

- rekomendacji do nagród i wyróżnień naukowych (np. Nagroda Wydziału I PAN im. W. Spasowskiego; Medal KNP PAN „Za Zasługi dla Rozwoju Polskiej Pedagogiki");

- upowszechniania bazy danych o adiunktach jako potencjalnych promotorach pomocniczych;

- organizacji konkursu na najlepszą pracę doktorską z pedagogiki;

- aktywności w powołanym przy KNP Zespole ds. Współpracy ze Studenckimi Kołami Naukowymi;

- włączania młodych naukowców do publikowania rozpraw w seriach wydawniczych oraz czasopismach naukowych pod patronatem KNP PAN;

- obejmowania patronatem konferencji naukowych; 
4. Włączanie się członków KNP PAN w szeroko pojmowanej przestrzeni publicznej w debaty, formułowanie komentarzy i ekspertyz na temat pedagogiki, edukacji, zmian w oświacie i szkolnictwie wyższym (np. udzielanie wywiadów, udział w programach mediów wizualnych itp.).

5. Kontynuowanie współpracy z innymi komitetami naukowymi PAN, udział we wspólnych konferencjach naukowych, pracach zespołów eksperckich, posiedzeniach Wydziału I Nauk Humanistycznych i Społecznych PAN.

Po raz pierwszy Komitet włączył do swojego składu w roli specjalistów na czas całej kadencji młodych pracowników naukowych, których rekomendowali dziekani wydziałów pedagogicznych. Byli to doktorzy, którzy w czasie kadencji potwierdzili swoje wysokie kompetencje i osiągnięcia naukowe, uzyskując do listopada 2019 roku stopień naukowy doktora habilitowanego: Ewa Bochno z Uniwersytetu Zielonogórskiego, Paweł Rudnicki z Dolnośląskiej Szkoły Wyższej we Wrocławiu, Joanna Wierzejska z Uniwersytetu Marii Curie-Skłodowskiej w Lublinie oraz oczekujący od maja 2019 roku na postępowanie habilitacyjne doktorzy: Agata Rzymełka-Frąckiewicz z Uniwersytetu Śląskiego w Katowicach, Radosław Nawrocki z Uniwersytetu im. Adama Mickiewicza, Wydział w Kaliszu, Sławomir Pasikowski z Uniwersytetu Łódzkiego oraz Piotr Zańko z Uniwersytetu Warszawskiego. W grupie specjalistów dokooptowano trzech samodzielnych pracowników naukowych, żeby możliwe było prowadzenie lub zainicjowanie prac zespołów problemowych: prof. Józefę Bałachowicz z APS w Warszawie (Zespół Edukacji Elementarnej), prof. Barbarę Smolińską-Theiss z APS w Warszawie (Zespół Pedagogiki Społecznej) i prof. APS Macieja Tanasia (Zespół Pedagogiki Medialnej). Obie decyzje były niezwykle trafne, gdyż także te zespoły KNP należały do jednych z najbardziej aktywnych $\mathrm{w}$ środowisku akademickiej pedagogiki oraz jako angażujące się z własnymi ekspertyzami w sferze publicznej.

\section{STANOWISKA KNP PAN W SPRAWACH OŚWIATY}

Nie była to „łatwa” kadencja ze względu na zaistniałe po wyborach parlamentarnych jesienią 2015 roku zmiany polityczne w kraju. Dla prac Komitetu nie miało to bezpośredniego znaczenia, gdyż zgodnie z prawem jego członkowie są zobowiązani do aktywności naukowej, a nie włączania się w działania związane $\mathrm{z}$ walką stronnictw politycznych w kraju. Tym niemniej z racji podporządkowania oświaty przez kolejny już rząd interesom partii władzy, centralistycznego sposobu sprawowania nadzoru pedagogicznego nad szkolnictwem członkowie KNP zabierali indywidualnie głos $\mathrm{w}$ mediach publicznych na temat zapowiadanych, a następnie wdrażanych przez Ministerstwo Edukacji Narodowej zmian ustrojowych, 
opiniowali przedkładane przez MEN projekty ustaw i rozporządzeń czy przedkładali w ramach aktywności w swoich uczelniach, towarzystwach naukowych lub stowarzyszeniach społecznych ekspertyzy i stanowiska o charakterze merytorycznym. Przykładem były tu indywidualne lub społeczne inicjatywy niektórych członków KNP na rzecz poparcia w 2018 roku przez Stowarzyszenie Pedagogów Społecznie Zaangażowanych pod przewodnictwem prof. Tadeusza Pilcha akcji protestacyjnej ZNP w sporze z rządem PiS czy wspierania pedagog społecznej prof. Uniwersytetu Śląskiego Ewy Jarosz w kandydowaniu na stanowisko Rzecznika Praw Dziecka. Jako przedstawiciele akademickiego środowiska pedagogicznego nie mieliśmy wątpliwości, że kandydatka była znakomitą specjalistką do objęcia tego urzędu.

W świetle jednak opinii Dziekana Wydziału I PAN prof. Stanisława Filipowicza - Komitet Nauk Pedagogicznych nie mógł włączyć się do tzw. komitetów poparcia któregokolwiek z kandydatów na Rzecznika Praw Dziecka, gdyż byłoby to naruszeniem statutowych funkcji PAN w związku z podjęciem działalności politycznej. Proces wyboru przez Sejm ma w Polsce charakter stricte polityczny. Mogliśmy zatem indywidualnie udzielać poparcia znakomitej kandydatce, która mimo dwukrotnie wznawianych przez Sejm procedur wyborczych nie uzyskała poparcia posłów partii władzy, toteż Rzecznikiem Praw Dziecka został polityk popierany przez stronę rządową.

Komitet Nauk Pedagogicznych zajął oficjalne stanowisko wobec procesów wdrażanej reformy systemu oświatowego, wskazując w nim na to, że jest ona nieprzygotowana merytorycznie, szkodliwa, bez właściwej diagnozy stanu polskiej edukacji, bez naukowo uzasadnionej wizji wychowania i kształcenia. Reforma szkolna w 2016 roku miała charakter polityczny, bazując na mechanizmie inżynierii społecznej, bez liczenia się ze środowiskiem oświatowym i naukowym. Merytoryczna krytyka władz, także w ramach bezpośredniego zaproszenia minister edukacji Anny Zalewskiej z dn. 20 czerwca 2016 roku na posiedzenie Komitetu, nie była brana przez nią pod uwagę.

Prowadzone przez środowisko pedagogiki akademickiej badania, wsłuchiwanie się w głosy społeczeństwa, konsultacje z przedstawicielami środowisk samorządów lokalnych oraz organizacji społecznych zaangażowanych we wspomaganie pracy dydaktyczno-wychowawczej szkoły upoważniały do zajęcia krytycznego stanowiska wobec przygotowania, wprowadzania oraz zauważalnych już negatywnych skutków reformy polskiego szkolnictwa. $Z$ dezaprobatą Komitet ocenił tryb i jakość konsultacji społecznych dotyczących najważniejszej decyzji dla przyszłości narodu, jego kultury i jego rozwoju. Niezrozumiały i nie do przyjęcia w tak zasadniczej sprawie był pośpiech wprowadzania reformy szkoły, który spowodował, że tak zwane konsultacje miały charakter pozorny, fasadowy i nie respektowały powszechnie zgłaszanych, a racjonalnych zastrzeżeń. 
Uchwałą z dn. 18 marca 2019 roku Komitet skierował do premiera Mateusza Morawieckiego apel o podjęcie przez władze systemowych zmian w polityce oświatowej, które zapewniłyby godne warunki do profesjonalnej realizacji zadań edukacyjnych przez nauczycieli wszystkich placówek oświatowo-wychowawczych dla dobra wychowanków i naszego społeczeństwa. Prowadzone od szeregu lat badania pedeutologiczne w tym środowisku zawodowym jednoznacznie wskazują na obniżający się status życia tych, którzy odpowiadają za jakość kształcenia młodych pokoleń.

Niestety, prowadzący przez stronę rządową negocjacje w Centrum Dialogu Społecznego z komitetem strajkowym nauczycieli upominających się o podwyższenie płac i godne traktowanie ich profesji, nie wyrazili w kwietniu 2019 roku zgody na włączenie w roli mediatorów członków prezydium KNP PAN (mnie i prof. Marka Konopczyńskiego). Konflikt nie został zakończony pozytywnie dla nauczycielskiego środowiska w wyniku zdominowania go przez władze państwowe szantażem etycznym (kwestia strajku okupacyjnego w trakcie egzaminów państwowych), krytyką strajkujących nauczycieli w mediach państwowych oraz brakiem możliwości zrekompensowania strajkującym utraty zarobków z tytułu udziału w akcji protestacyjnej. Zawieszenie przez ZNP akcji strajkowej pozostawiło środowisko nauczycielskie w głębokiej frustracji, skutkując odejściem z zawodu, także porzuceniem członkostwa w nauczycielskich związkach zawodowych przez tysiące nauczycieli.

\section{STANOWISKA KNP PAN W SPRAWACH NAUKI I SZKOLNICTWA WYŻSZEGO}

KNP zajmował także stanowisko wobec projektowanych i wdrażanych przez Ministerstwo Nauki i Szkolnictwa Wyższego zmian w tym obszarze edukacji i nauki. W lutym 2018 roku poparł apel 145 naukowców o zmiany w planie reformy nauki ministra J. Gowina, w którym pozytywnie odniósł się do wycofania się resortu z pomysłu tajnych recenzji w przewodach habilitacyjnych i wnioskach profesorskich, poparł ideę zrzeszania się uczelni, tworzenia „szkół doktorskich” oraz możliwość suwerennego wprowadzenia przez uczelnie egzaminów wstępnych. Krytycznie Komitet odniósł się do: skandalicznie niskich nakładów na naukę i szkolnictwo wyższe; skrócenia wieku zatrudnienia uczonych: kobiet do 60 i mężczyzn do 65 roku życia; podporządkowania uniwersytetów mechanizmom i podmiotom korporacyjnym; kryteriów ewaluacji dyscyplin naukowych w sytuacji braku resortowego wykazu czasopism i wydawnictw naukowych; zagrożeń związanych z upolitycznieniem i ideologicznym kryterium finansowania badań naukowych. W 2018 roku poparł akcję strajkową naukowców, doktorantów, studentów i pracowników pozaakademickich na Uniwersytecie Warszawskim 
w związku z procedowaniem w Sejmie Ustawy 2.0 dotyczącej reform w szkolnictwie wyższym i nauce.

W marcu 2019 roku Komitet skierował do ministra J. Gowina wniosek o zmianę w konkurowaniu uczonych o środki w Narodowym Centrum Nauki. Skoro ewaluacji podlegają dyscypliny naukowe, to w ten sam sposób powinny być traktowane wnioski o granty w NCN, to znaczy, że konkursy powinny odbywać się nie w ramach grup dyscyplin, ale wyłącznie w ramach poszczególnych dyscyplin. Komitet apelował zatem o rzetelne i adekwatne do zasad ewaluacji w nauce procedowanie konkursowe w NCN. Największym sukcesem KNP było doprowadzenie w 2016 roku do unieważnienia turystyki habilitacyjnej i zmiany bilateralnej umowy o uznawaniu stopni naukowych między Polską a Słowacją².

Podjęto także uchwałę w sprawie projektu rozporządzenia MNiSW o dziedzinach i dyscyplinach naukowych, w którym pojawiła się jako dyscyplina naukowa nie „Pedagogika”, ale „Pedagogika i nauki o edukacji”. Ministerstwo przychyliło się do interpelacji i w rozporządzeniu o dziedzinach i dyscyplinach nauk przyjęło pedagogikę. Mimo interpelacji KNP w Sejmie VIII kadencji wniosek Prezydium KNP PAN w kwestii projektowanej likwidacji przez MNiSW ogólnokrajowego wykazu czasopism naukowych B i C nie został przyjęty. Wprowadzono jedną listę czasopism punktowanych, której procedura powstania i kryteria oceny zostały oprotestowane przez KNP w sierpniu 2019 roku.

\section{PROBLEMATYKA DEBAT NAUKOWYCH KNP PAN}

Posiedzenia KNP PAN odbywały się regularnie, cztery razy w roku, w trakcie których każdorazowo wygłaszane były przez członków Komitetu referaty naukowe i dyskusje, także z udziałem zapraszanych gości, naukowców, przedstawicieli władz rządzących, ustawodawczych i samorządowych oraz przedstawicieli organizacji pozarządowych. Zależało nam na tym, by sprawy oświaty, nauki i szkolnictwa wyższego były analizowane w konfrontacji z bieżącą polityką w kraju oraz stanem badań naukowych w naukach społecznych, a zarazem, by także młodzi naukowcy mieli możliwość podzielenia się wynikami własnych badań pedagogicznych. W trakcie posiedzeń referowane zatem były następujące zagadnienia:

I. POLITYKA OŚWIATOWA-EDUKACJA SZKOLNA I ŚRODOWISKOWA:

- Pedagogika wobec projektowanych $i$ wdrażanych zmian oświatowych (Bogusław Śliwerski);

- Sytuacja dzieci w Polsce (Barbara Smolińska-Theiss);

2 B. Śliwerski, Turystyka habilitacyjna Polaków na Stowację w latach 2005-2016, Wydawnictwo UŁ, Łódź 2018. 
- Tendencje reformowania edukacji specjalnej (Zenon Gajdzica);

- Polityka w stużbie edukacji, edukacja w stużbie polityki (Radosław Nawrocki);

- Problematyki rekonstrukcji sieci szkolnych oraz realnych problemów samorzadów i matych szkót prowadzonych przez organizacje społeczne (wyniki własnych badań) (Paweł Rudnicki);

- Polityka oświatowa wobec dzieci i młodzieży na wsi (Tadeusz Pilch);

- Między kontestacja a animacja. Praktyki kulturowe Dariusza Paczkowskiego w świetle trzyletnich badań etnograficznych; Pedagogie patriotyzmu (Piotr Zańko);

- Polska szkoła po strajku. Perspektywy i drogi wyjścia z kryzysu (Zbigniew Kwieciński);

- Przyszłość polskiej szkoły. Spoleczne oczekiwania interesariuszy wobec szkoty i systemu edukacji - wstepny raport z diagnozy Fundacji Kaleckiego (Marek Konopczyński);

- Problematyka praw dziecka w świetle działań Rzecznika Praw Dziecka oraz zwiazanych z wyborami na nowa kadencje jego następcy (Marek Michalak - Rzecznik Praw Dziecka);

II. SZKOLNICTWO WYŻSZE I NAUKA:

- Uprawianie pedagogiki w zmieniajacych się kontekstach życia akademickiego, społecznego i kulturalnego (ks. Marian Nowak);

- Nowa kadencja wtadz akademickich uczelni i ich jednostek a rola wspótpracy $i$ wsparcia ze strony KNP PAN; Pedagogika polska w świetle analiz postępowań naukowych $w$ Centralnej Komisji. Raport z badań; Ustawa 2.0 - ijej implikacje dla awansów naukowych z pedagogiki; Problem jakości badań pedagogicznych i recenzji w awansach naukowych pedagogów oraz osób z pogranicza; Pedagogika w nowych warunkach reformy szkolnictwa wyższego i konstytuujacej ja ustawy oraz rozporządzeń $M N i S W$ (Bogusław Śliwerski);

- „Dydaktyka zaangażowana” jako podstawa ksztatcenia studentów specjalności nauczycielskich - z doświadczeń Katedry Dydaktyki i Edukacji Szkolnej KUL (Krystyna Chałas);

- Prace polskiego Sejmu nad nowelizacja ustaw o szkolnictwie wyższym oraz o stopniach i tytule naukowym (Jacek Kurzępa);

- Polityka szkolnictwa wyższego w zakresie parametryzacji osiagnięć naukowych $i$ wobec projektów wprowadzanych zmian $w$ akademickich ustawach i rozporzadzeniach; Po Kongresie Nauki Polskiej w Krakowie; Stan prac nad reforma szkolnictwa wyższego (Barbara Kromolicka);

- Kompetencje relacyjne pedagoga - teoretyczne i empiryczne uzasadnienia potrzeby ich posiadania (Krystyna Ablewicz); 
- Po co i czego ucza się przyszli polscy nauczyciele?; O co chodzi w „nowym” kształceniu nauczycieli? (Dorota Klus-Stańska);

- Kształcenie nauczycieli w świetle procedur i doświadczeń eksperta Polskiej Komisji Akredytacyjnej; Kwalifikacje pedagogiczne a kwalifikacje nauczycielskie - Kontekst nauczania przedmiotowego (Amadeusz Krause);

- Tożsamość uniwersytetu w kulturze niepewności; Pasja i tożsamość naukowca (Zbyszko Melosik);

- Pedagogika (jako dyscyplina naukowa i kierunek studiów) w świetle proponowanej ustawy Prawo o szkolnictwie wyższym (Roman Leppert);

- Wstepna analiza ksztatcenia metodologicznego na kierunku pedagogika (Sławomir Pasikowski);

- Kompetencje spoleczno-emocjonalne kandydatów na nauczycieli wczesnej edukacji. Wyniki badań (Stefan Tomasz Kwiatkowski);

- Zastosowanie aplikacji komputerowej Atlas.ti. w analizie jakościowej wywiadów (Piotr Zańko).

WKŁAD KNP PAN W KSZTAŁCENIE KADR AKADEMICKICH

Odbyły się cztery Letnie Szkoły Młodych Pedagogów KNP PAN: XXX w Katowicach/Wiśle - współorganizator: Wydział Pedagogiki i Psychologii Uniwersytetu Śląskiego, temat: Pułapki badań nad edukacja (2016); XXXI w Warszawie - współorganizator: Wydział Nauk Pedagogicznych Uniwersytetu Kardynała Stefana Wyszyńskiego w Warszawie, temat: Problemy z własnym lub cudzym warsztatem pisarstwa naukowego (2017); XXXII - w Zielonej Górze/ Łagowie - współorganizator: Wydział Pedagogiki, Socjologii i Psychologii Uniwersytetu Zielonogórskiego, temat: Kultura Szkoły: Czym ona jest? Jak ja badać i o niej pisać? (2018) oraz XXXIII im. Prof. Marii Dudzikowej w Olsztynie/ Łańsku - współorganizator: Wydział Nauk Społecznych Uniwersytetu Warmińsko-Mazurskiego w Olsztynie, temat: Wspótczesny nauczyciel - profesjonalizm mistrzostwo - misja publiczna (2019). Członkami Centralnej Komisji Do Spraw Stopni i Tytułów są członkowie KNP PAN: Zbyszko Melosik (do października 2019), Jerzy Nikitorowicz (od listopada 2019), Władysława Szulakiewicz, Bogusław Śliwerski, natomiast do składu pierwszej kadencji Rady Doskonałości Naukowej zostali wybrani: ks. Marian Nowak, Władysława Szulakiewicz i Bogusław Śliwerski.

Komitet współorganizował w tej kadencji dwa Ogólnopolskie Zjazdy Pedagogiczne, których organizatorem jest Polskie Towarzystwo Pedagogiczne, zaś 
współgospodarzem jeden z uniwersytetów. W 2016 roku członkowie KNP współtworzyli Komitet Programowy IX Zjazdu Pedagogicznego w Białymstoku, którego wiodący temat obrad brzmiał: Ku życiu wartościowemu. Idee - Koncepcje Praktyki ${ }^{3}$.

W 2018 roku została przyznana na wniosek KNP przez Wydział I PAN - Nagroda Naukowa im. Władysława Spasowskiego z pedagogiki panu dr. hab. Michałowi Klichowskiemu z Wydziału Studiów Edukacyjnych UAM w Poznaniu za rozprawę naukową pt. Learning in CyberParks. A Theoretical and Empirical Study ${ }^{4}$. Natomiast Polskie Towarzystwo Pedagogiczne w latach 2017-2019 wyróżniło Medalem PTP w dowód uznania szczególnych zasług na rzecz rozwijania nauk pedagogicznych oraz popularyzacji ich osiągnięć w kraju i za granicą następujących członków KNP PAN: Marię Czerepaniak-Walczak, Marię Dudzikową, Stefana M. Kwiatkowskiego, Zbigniewa Kwiecińskiego, Zbyszko Melosika, Jerzego Nikitorowicza, Bogusława Śliwerskiego i Irenę Wojnar.

Komitet przyznaje dzięki inicjatywie i wydaniu przez prof. Marka Konopczyńskiego - Medal Za Zastugi Dla Rozwoju Polskiej Pedagogiki. W latach 2017-2019 powołana Kapituła KNP wręczyła Medal następującym pedagogom: Oldze Czerniawskiej, Marii Dudzikowej, Józefowi Górniewiczowi, Teresie Hejnickiej-Bezwińskiej, Andrzejowi Jaczewskiemu, Marii Jakowickiej, Alicji Kargulowej, Tadeuszowi Lewowickiemu, Ewie Marynowicz-Hetce, Januszowi Moosowi, Jerzemu Niemcowi, Eugenii Potulickiej, Karolowi Poznańskiemu, Bogdanowi Szczepankowskiemu oraz Zygmuntowi Wiatrowskiemu. W uznaniu zasług dla rozwoju nauk pedagogicznych członkowie KNP PAN zostali wyróżnieni godnością doktora honoris causa przez senaty uniwersytetów: Tadeusz Lewowicki (2019 - Uniwersytet Śląski), Zbyszko Melosik (2018 - Uniwersytet Szczeciński) i Bogusław Śliwerski (2016 - Uniwersytet Kazimierza Wielkiego w Bydgoszczy oraz 2018 - Katolicki Uniwersytet Lubelski Jana Pawła II w Lublinie). Niestety, władzom Komitetu przyszło pożegnać w okresie tej kadencji zmarłych profesorów pedagogiki, tak byłych członków Komitetu: Kazimierza Denka (1932-2016), Roberta Kwaśnicę (1948-2018) i Władysława Piotra Zaczyńskiego (1930-2017), jak i wieloletnią wiceprzewodniczącą KNP, kierującą przez 25 lat Letnimi Szkołami Młodych Pedagogów - Marię Dudzikową (1938-2018).

3 M. Czerepaniak-Walczak, J. Madalińska-Michalak, B. Śliwerski (red.), Ku życiu wartościowemu. Idee - Koncepcje - Praktyki, t. 1, Idee - Koncepcje, Oficyna Wydawnicza „Impuls”, Kraków 2018; W. Danilewicz, J. Nikitorowicz, M. Sobecki (red.), Ku życiu wartościowemu. Idee - Koncepcje - Praktyki, t. 2, Koncepcje - Praktyki, Oficyna Wydawnicza „Impuls”, Kraków 2018.

4 M. Klichowski, Learning in CyberParks. A Theoretical and Empirical Study, Wydawnictwo Naukowe UAM, Poznań 2017. 


\section{WSPÓŁPRACA ZAGRANICZNA}

Komitet prowadzi od 25 lat intensywną współpracę z Narodowym Komitetem Nauk Pedagogicznych Ukrainy, włączając się w wymianę wyników badań naukowych, wspólne publikacje - monografie, w tym przekłady na oba języki, wydawanie wspólnych czasopism oraz w budowanie kultury transformatywnego oporu na rzecz rozwijania obywatelskiego społeczeństwa w obu krajach. Szkolnictwo wyższe może w tym zakresie odegrać istotną rolę, dlatego KNP PAN patronuje międzynarodowym, cyklicznym forom naukowym Ukraina/Polska, Polska/Ukraina, które odbywają się co dwa lata naprzemiennie w naszych państwach. Prowadzimy współpracę ponad podziałami, ponad nieczytelnością czy propagandową manipulacją, by przekraczane były granice na rzecz budowania w każdym z środowisk akademickich mistrzostwa pedagogicznego.

W ramach powyższej współpracy Wydział Pedagogiki i Psychologii Uniwersytetu Kazimierza Wielkiego w Bydgoszczy był współorganizatorem i gospodarzem VII Forum Naukowego Polska/Ukraina pod wiodącym tematem: „Edukacja dla przyszłości” (wrzesień 2017) , zaś Uniwersytet w Perejasławiu-Chmielnickim na Ukrainie zorganizował we wrześniu 2019 roku VIII Forum Naukowe Ukraina/ Polska, nadając jako wiodący dla debat temat: „Edukacja dla pokoju”. W dowód uznania osiągnięć naukowych w ramach współpracy z ukraińskimi pedagogami prof. dr hab. Stefan M. Kwiatkowski otrzymał w 2017 roku godność doktora honoris causa na Uniwersytecie Drogomanowa w Kijowie, zaś B. Śliwerskiemu nadano w 2019 roku godność doktora honoris causa Narodowej Akademii Nauk Pedagogicznych Ukrainy.

\section{WYDAWNICTWA NAUKOWE KNP}

Komitet wydaje dwa własne periodyki: „Rocznik Pedagogiczny” (do 2018 roku - 13 pkt), „Studia Pedagogiczne” (do 2018 roku - 10 pkt). Ten ostatni wydawany jest od 2018 roku w języku angielskim pod nazwą: „Polish Journal of Educational Studies”. Patronatem objęto następujące czasopisma: „Resocjalizacja Polska” (od 2019 roku - 70 pkt); od 2019 roku mającym 20 pkt: „Problemy Wcze-

5 R. Gerlach (red.), Edukacja dla przyszłości w świetle wyzwań XXI wieku, Wydawnictwo Uniwersytetu Kazimierza Wielkiego, Bydgoszcz 2017; R. Gerlach, R. Tomaszewska-Lipiec (red.), Edukacja dla przyszłości w perspektywie orientacji na rynek pracy, Wydawnictwo Uniwersytetu Kazimierza Wielkiego, Bydgoszcz 2017.

6 W. Kremień, W.P. Kocur, N.G. Niczkało, F. Szlosek (red.), Oswita dlja miru. Edukacja dla pokoju. Zbiór prac naukowych, t. 1-3, Widawnictwo TOB ,Jurka Ljubczenka”, Kijów-PerejasławChmielnicki 2019. 
snej Edukacji” (UG); „Horyzonty Wychowania” (Ignatianum); „Przegląd Pedagogiczny” (UKW), „Forum Pedagogiczne” (UKSW), „Pedagogika Społeczna” (Pedagogium), „Paedagogia Christiana” (UMK), „Biuletyn Historii Wychowania” (UAM) oraz pozostałe periodyki: „Parezja - Forum Młodych Pedagogów” (UwB), „Chowanna” (UŚ), „Studia z Teorii Wychowania” (ChAT). Od 2018 roku PAN zaprzestał dotowania „Rocznika Pedagogicznego”, a także zapowiedziano pozbawienie redakcji patronatu PAN, w związku z czym złożony został do władz Akademii protest ${ }^{7}$.

W latach 2016-2019 pod patronatem KNP kontynuowano wydawanie monografii naukowych $\mathrm{w}$ dwóch seriach wydawniczych, które są redagowane przez członków Komitetu, a mianowicie:

1) Seria Oficyny Wolters-Kluwer w Warszawie: Kultura szkoty, red. Maria Dudzikowa (do 2018 roku), od 2019 roku - Bogusław Śliwerski, Ewa Bochno $^{8}$

2) Seria Oficyny Wydawniczej „Impuls” w Krakowie: Pedagogika Nauce i Praktyce, red. Bogusław Śliwerski ${ }^{9}$.

Choroba Marii Dudzikowej sprawiła, że została zawieszona edycja pod jej współredakcją serii Oficyny Wydawniczej „Impuls” w Krakowie: Palace Problemy Edukacji i Pedagogiki, red. Maria Dudzikowa (do 2018 roku) z Marią Czerepaniak-Walczak $^{10}$.

7 Z. Kwieciński, List w sprawie zaprzestania finansowania Rocznika Pedagogicznego przez PAN, „Rocznik Pedagogiczny” 2017, t. 40; B. Śliwerski, O decyzji władz Polskiej Akademii Nauk w sprawie nowych regut finansowania publikacji naukowych ze środków DUN począwsy od 2018 roku, „Rocznik Pedagogiczny” 2017, t. 40.

${ }^{8}$ M. Dudzikowa, S. Jaskulska (red.), Twierdza. Szkoła w metaforze militarnej. Co w zamian?, Wolters Kluwer, Warszawa 2016; B. Śliwerski, Meblowanie szkolnej demokracji, Wolters Kluwer, Warszawa 2017; M. Czerepaniak-Walczak, Proces emancypacji kultury szkoty, Wolters Kluwer, Warszawa 2018; A. Babicka-Wirkus, Kultury oporu w szkole. Działania - motywacje - przestrzeń, Wolters Kluwer, Warszawa 2019.

9 J. Nikitorowicz, Etnopedagogika w kontekście wielokulturowości i ustawicznie kształtującej się tożsamości, Oficyna Wydawnicza „Impuls”, Kraków 2017; B. Śliwerski, Habilitacja. Diagnoza. Procedury. Etyka. Postulaty, Oficyna Wydawnicza „Impuls”, Kraków 2017; K. Maliszewski, D. Stępkowski, B. Śliwerski, Istota, sens i uwarunkowania (wy)ksztatcenia, Oficyna Wydawnicza „Impuls”, Kraków 2019.

${ }^{10}$ Do 2015 roku ukazały się: M. Dudzikowa, K. Knasiecka-Falbierska (red.), Sprawcy i/lub ofiary działań pozornych w edukacji szkolnej, Oficyna Wydawnicza „Impuls”, Kraków 2013; Z. Gajdzica (red.), Człowiek z niepetnosprawnościa w rezerwacie przestrzeni publicznej, Oficyna Wydawnicza „Impuls”, Kraków 2013; J. Nikitorowicz (red.), Patriotyzm i nacjonalizm. Ku jakiej tożsamości kulturowej?, Oficyna Wydawnicza „Impuls”, Kraków 2013; M. Czerepaniak-Walczak (red.), Fabryki dyplomów czy universitas?, Oficyna Wydawnicza „Impuls”, Kraków 2013; D. Klus-Stańska (red.), (Anty)edukacja wczesnoszkolna, Oficyna Wydawnicza „Impuls”, Kraków 2014; H. Kwiatkowska (red.), Uczłowieczyć komunikację. Nauczyciel wobec ucznia w przestrzeni szkolnej, Oficyna Wydawnicza „Impuls”, Kraków 2015. 


\section{PODSUMOWANIE}

Po raz pierwszy w dziejach PAN zostały merytorycznie i parametrycznie ocenione w 2013 roku wszystkie komitety naukowe. W Wydziale I Nauk Humanistycznych i Społecznych PAN są 24 komitety naukowe, przy tym większość z nich posiada w PAN instytuty naukowe, których kadra wzmacnia ich działalność i pozycję. Komitet Nauk Pedagogicznych od powstania PAN w 1953 roku nie ma swojego instytutu naukowego, a mimo to społeczna działalność jego członków w latach 2011-2013 została oceniona przez Radę Kuratorów Wydziału I na wicemistrzowską, bowiem KNP zająı II miejsce po Komitecie Nauk o Literaturze PAN, a przed Komitetem Nauk Historycznych (III miejsce), ex aequo IV miejsce - Komitet Językoznawstwa i Komitet Psychologii, V miejsce - Komitet Nauk Demograficznych, a VI miejsce - Komitet Nauk Prawnych. Kryterium oceny tak w pierwszej, jak i następnej ocenie parametrycznej komitetów naukowych były: działalność wewnątrzorganizacyjna, wydawnicza, ekspercka, organizowanie konferencji, działalność opiniodawcza i opiniotwórcza, inicjująca i integrująca oraz upowszechniająca w środowiskach naukowych osiągnięcia teoretyczno-metodologiczne swoich i pokrewnych dyscyplin.

Ponowna ocena parametryczna w 2018 roku nie tylko potwierdziła, ale i uwydatniła znakomitą aktywność naszej wspólnoty korporacyjnej, bowiem KNP uzyskał w Wydziale I Nauk Humanistycznych i Społecznych PAN - I miejsce (ex aequo z Komitetami Nauk Etnologicznych, Komitetem Nauk o Kulturze Antycznej, Komitetem Nauk o Literaturze) z liczbą 95 pkt na 100. Wszyscy członkowie Komitetu mogą mieć poczucie zasłużonej satysfakcji, a zarazem potwierdzenie zasadnie przyjętej przez Prezydium KNP PAN strategii jeszcze bardziej dynamicznego i kreatywnego włączania się w życie akademickie i dokonania naukowe w naszym kraju, inicjowania wielu przedsięwzięć na rzecz polskiej edukacji, w przestrzeni publicznej oraz przywrócenia szacunku dla profesjonalizmu akademików w suwerennym prowadzeniu badań czy wykonywaniu ekspertyz. Dziękuję wszystkim członkom KNP PAN obu kadencji, w czasie których przyszło mi kierować tak znakomitym gremium uczonych, za społeczne zaangażowanie w rozwój nauk o wychowaniu, kształcenie i doskonalenie kadr akademickich oraz troszczenie się o dobre imię środowiska akademickiej pedagogiki. 